the present case is that the retinal changes are considerably larger and more clearly defined than those which have been observed in what one might usefully term "eclipse epidemics " of this condition." It is presumed that both the greater reduction of vision and the. more marked appearances in this particular case could well be due to the very prolonged gazing at the sun which his delusions appear to have prompted.

This case fully underlines the dangers of sun-gazing and watching either when special solar phenomena are pending or for any other reason. I should like once again to reiterate the advice of Flynn ${ }^{2}$ that for the lay public the simplest and safest way of inspecting the sun's disc is by use of the pinhole projection method.-I am, etc.,

Sussex Eye Hospital,

$$
\text { M. J. Gilkes. }
$$

Brighton.

REFERENCES 1 Gilkes, M. J., Macpherson, D. G., Osmond,
A. H., Thorne, B. T., Roberts, D. St. C., Brit.
med. Y., 1959, 2, 1487. 2 Flynn, J. A. F., Brit. med. F., 1960, 1, 563.
Exophthalmos and Stenosed Aqueduct of Sylvius

SIR,-The recent report by Dr. R. Greene and Mr. L. C. Oliver of a patient with thyrotoxicosis and exophthalmos, the features of which appeared to recede pari passu with the surgical relief of hydrocephalus due to a stricture of the aqueduct, is very interesting (17 August, p. 412). The authors regard their case as unique, and consider that the concomitant development of hydrocephalus and its remission after drainage of the aqueduct must be related, although they cannot explain it. They discount the notion that the two sets of phenomena might be coincidental

Dr. Stewart Alexander and I have already reported a not dissimilar case of a 60 -yearold woman with bilateral malignant exophthalmos with chemosis, marked ophthalmoplegia, and papilloedema. She did not have a goitre or thyrotoxicosis, although there was slight excess of pituitary thyrotropin in her blood. ${ }^{2}$ All these features had steadily advanced during the preceding three months. Yet within a day after an operation in which only one orbit had been decompressed, they began to recede simultaneously on both sides. Six weeks later all features of her disease, including the excess of pituitary thyrotropin, had disappeared completely. Subsequently I was able to follow her up for more than 15 years and her eye symptoms did not return. The late Lord Brain evidently had had similar experiences, for he wrote, "A curious and unexplained feature of it (orbital decompression), to which attention has been drawn before, is that sometimes, when the worst eye is operated on first, the other improves so much that it does not need operation."s

The explanation for these coincidental improvements is not at all obvious and no current hypothesis satisfies the facts.-I am, etc.,

\section{Guy's Maudsley Neurosurgical Unit \\ London S.E.S.}

\section{REFERENCES}

Falconer, M. A., and Alexander, W. S., Brit. 7. Ophthal., $195 \mathrm{i}, 35,253$. Ophthal. Soc. U.K.,

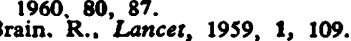

\section{Anaesthesia for Insertion of Arteriovenous Cannulae}

SIR,-Having just received the B.M.F. I was interested in the correspondence on anaesthesia for insertion of arteriovenous cannulae (15 June, p. 702).

We have used at our centre a combination of neuroleptic sedation and axillary nerve block for the last 60 shunts, which have included 16 kidney transplant cases. As we insist on an indwelling intravenous needle for every nerve block, we use this route to administer dehydrobenzperidine (average dose 7.5-10 mg.) 10-15 minutes preoperatively. For actual anaesthesia we prefer axillary nerve block with $2 \%$ lignocaine. In experienced hands with the single injection technique we have found the results to be very satisfactory, painless, and accompanied with marked sedation.-I am, etc.,

Department of Anaesthesia,

H. J. Birkhan. Rambam Government Hospital,

\section{Anaesthetists and Crossword Puzzles}

SIR,-Dr. Alec Paton, in his entertaining “Personal View" (17 August, p. 431), wonders why so few anaesthetists are recruited from the ranks of the book-addicts. He points out that they seldom get past the crossword-puzzle stage.

This is just as well: even moderate performers seldom spend more than two minutes worrying at one clue before moving on to the next. (On B.B.C.-2 the ration is thirty seconds per clue.) It takes four minutes of total anoxia for permanent brain damage to ensue. Thus the crossword is ideal for the anaesthetist, who can glance at the patient at least once every two minutes. If he became engrossed in, say, "All the world's a stage" the patient might well come out of the anaesthetic " sans everything." - I am, etc.,

\section{Department of Mental Health,}

W. O. MCCORMICK.

Queen's University,

\title{
Guanethidine and Glucose Tolerance in Diabetics
}

SIR,-Dr. C. A. Lillicrap and I have raised intravenous administration of guanethidine the possibility of a significant antidiabetic action of guanethidine (15 June, p. 697). Stopping guanethidine administration in a diabetic patient led to increased blood sugar levels and increased insulin requirements. This patient was receiving $20 \mathrm{mg}$. guanethidine daily for control of hypertension, and an additional 24 units of soluble insulin a day were required after stoppage of guanethidine administration. The issues were not quite simple, however, since this patient was also leads to liberation of adrenaline from sympathetic nerve endings and also hyperglycaemia. On the other hand chronic administration of guanethidine leads to depletion of tissue catecholamines, a fall in blood sugar, and improvement in oral glucose tolerance tests in diabetic subjects as shown in the present study.

Studies of plasma insulin levels before and during guanethidine administration would be needed before drawing any conclusions about

Oral Glucose Tolerance Tests before and during Guanethidine Treatment

\begin{tabular}{|c|c|c|c|c|c|c|c|c|}
\hline & & Dose & Fasting & hr. & $1 \mathrm{hr}$. & $1 \geqq \mathrm{hr}$. & $2 \mathrm{hr}$. & $21 \mathrm{hr}$. \\
\hline $\begin{array}{c}\text { Case } \\
1\end{array}$ & $\begin{array}{l}\text { Before treatment } \\
\text { After } 7 \text { days' treatment } \\
\end{array}$ & $50 \mathrm{mg}$. daily & $\begin{array}{l}110 \\
+10 \\
\end{array}$ & $\begin{array}{l}187 \\
-67 \\
\end{array}$ & $\begin{array}{l}228 \\
-51 \\
\end{array}$ & $\begin{array}{l}228 \\
-30 \\
\end{array}$ & $\begin{array}{l}198 \\
-28 \\
\end{array}$ & $\begin{array}{l}173 \\
-10 \\
\end{array}$ \\
\hline Case & $\begin{array}{l}\text { Before treatment } \\
\text { After } 5 \text { days' treatment } \\
\text { After } 14 \text { days' treatment } \\
\end{array}$ & $\begin{array}{l}60 \mathrm{mg} \text {. daily } \\
60 \mathrm{mg} \text {. daily }\end{array}$ & $\begin{array}{l}260 \\
-29 \\
-19 \\
\end{array}$ & $\begin{array}{r}294 \\
-70 \\
-117 \\
\end{array}$ & $\begin{array}{l}327 \\
-75 \\
-95\end{array}$ & $\begin{array}{l}344 \\
-42 \\
-92\end{array}$ & $\begin{array}{l}344 \\
-76 \\
-83\end{array}$ & $\begin{array}{l}315 \\
-51 \\
-\end{array}$ \\
\hline$\underset{3}{\text { Case }}$ & $\begin{array}{l}\text { Before treatment } \\
\text { After } 5 \text { days' treatment } \\
\text { After } 14 \text { days' treatment }^{\circ}\end{array}$ & $\begin{array}{l}60 \mathrm{mg} \text {. daily } \\
90 \mathrm{mg} \text { daily from } \\
6 \text { th to } 14 \text { th days }\end{array}$ & $\begin{array}{l}131 \\
+14 \\
-25\end{array}$ & $\begin{array}{l}224 \\
+16 \\
-43\end{array}$ & $\begin{array}{l}302 \\
-54 \\
-58\end{array}$ & $\begin{array}{l}232 \\
-20 \\
-36\end{array}$ & $\begin{array}{l}201 \\
-49 \\
-63\end{array}$ & $\begin{array}{l}166 \\
-32 \\
-64\end{array}$ \\
\hline
\end{tabular}

The figures after treatment refer to the change in blood glucose levels at the stated times.

receiving bendrofluazide, and guanethidine has been shown to reduce the hyperglycaemic response to diazoxide-another thiazide-in adrenal demedullated rats.'

This communication describes results of oral glucose tolerance tests in three maturity onset type diabetic subjects before, and 5-14 days after, guanethidine administration. All three patients had hypertension, were admitted to hospital one week before the study was commenced, and were on unrestricted diets before and during the study. Oral glucose tolerance tests were performed accord. ing to the recommendation of the British Diabetic Association. ${ }^{2}$ Results of the study are shown in the Table.

It is clear that during guanethidine administration there is a highly significant improvement in oral glucose tolerance tests in all cases. The mechanism of antidiabetic actions of guanethidine is uncertain. Acute the mechanism of the antidiabetic action of guanethidine. It is of some interest that guanethidine, being a guanidine derivative, is a distant relative of biguanides, which are already in use as oral antidiabetics. Further work is in progress to evaluate the role of guanethidine as an oral antidiabetic.

I wish to thank Dr. C. A. Lillicrap, consultant physician, County Hospital, Lincoln, for permitting me to study the above patients under his care.

-I am, etc.,

Atkinson Morley's Hospital,
London S.W.20.

K. K. Gupta

REFERENCES

Janes, R. G., Roelf, R. J. and Wilson, W. R., 2 Fitzgerald, M. G., and Keen, H., Brit. med. $7 .$,
1964, 1, 1568 . 